\title{
In vitro mycelial sensitivity of Macrophomina phaseolina to fungicides ${ }^{1}$
}

\author{
Rosane Fátima Baldiga Tonin², Aveline Avozani², \\ Anderson Luiz Durante Danelli², Erlei Melo Reis ${ }^{2}$, Sandra Maria Zoldan², Felipe Rafael Garcés-Fiallos ${ }^{3}$
}

\begin{abstract}
RESUMO
Sensibilidade micelial in vitro de Macrophomina phaseolina a fungicidas

A podridão negra das raízes, causada por Macrophomina phaseolina (Tass.) Goid., é a doença radicular mais comum em áreas cultivadas com soja. Este trabalho objetivou determinar a sensibilidade micelial in vitro, medida pela $\mathrm{CI}_{50}$ (concentração para inibir $50 \%$ do crescimento miceliano do fungo) de um isolado de $M$. phaseolina obtido de soja, a diferentes fungicidas (thiram, iprodione, carbendazim, piraclostrobina, fluquinconazole, tolifluanida, metalaxil e penflufen + trifloxistrobina), em seis concentrações (0,01 mg L-1; $0,10 \mathrm{mg} \mathrm{L}^{-1} ; 1,00 \mathrm{mg} \mathrm{L}^{-1} ; 10,00 \mathrm{mg} \mathrm{L}^{-1} ; 20,00 \mathrm{mg} \mathrm{L}^{-1}$; e 40,00 $\mathrm{mg} \mathrm{L}^{-1}$ do ingrediente ativo). A concentração de $0,00 \mathrm{mg} \mathrm{L}^{-1}$ representou a testemunha, sem adição de fungicida. A avaliação do crescimento miceliano foi realizada com o auxílio de paquímetro digital, medindo-se o diâmetro das colônias, quando o crescimento do fungo no tratamento testemunha atingiu a borda da placa de Petri. O delineamento experimental foi inteiramente casualizado, com quatro repetições. Quanto à fungitoxicidade dos ingredientes ativos, evidenciou-se variação de atóxicos a altamente fungitóxicos, para o isolado de $M$. phaseolina, com valores para $\mathrm{CI}_{50}$ situando-se entre $0,23 \mathrm{mg} \mathrm{L}^{-1} \mathrm{e}>40,00 \mathrm{mg} \mathrm{L}^{-1}$, sendo o carbendazim o mais eficiente $\left(\mathrm{CI}_{50}=0,23 \mathrm{mg} \mathrm{L}^{-1}\right)$. O fungo apresentou insensibilidade aos ingredientes ativos fluquinconazole, metalaxil, tiram e tolifluanida.
\end{abstract}

PALAVRAS-CHAVE: Glycine max L.; podridão radicular; fungitoxidade; $\mathrm{CI}_{50}$.

\section{INTRODUCTION}

Black root rot, popularly known as charcoal rot, is a disease commonly found in soybean fields. This pathogen can infect roots, stems, leaves and pods of different plant species, affecting more than 500 economic crops (Sinclair \& Backman 1989, Almeida et al. 2001). Its causal agent is the Macrophomina phaseolina (Tass.) Goid. fungus (Sinclair \& Backman

\section{ABSTRACT}

Black root rot, caused by Macrophomina phaseolina (Tass.) Goid., is the most common root disease in soybean fields. This study aimed to determine the in vitro mycelial sensitivity, measured by the $\mathrm{IC}_{50}$ (concentration to inhibit $50 \%$ of the fungus mycelial growth) of a M. phaseolina isolate obtained from soybean, to different fungicides (thiram, iprodione, carbendazim, pyraclostrobin, fluquinconazol, tolyfluanid, metalaxyl and penflufen + trifloxystrobin), at six concentrations $\left(0.01 \mathrm{mg} \mathrm{L}^{-1}, 0.10 \mathrm{mg} \mathrm{L}^{-1}, 1.00 \mathrm{mg} \mathrm{L}^{-1}, 10.00 \mathrm{mg} \mathrm{L}^{-1}\right.$, $20.00 \mathrm{mg} \mathrm{L}^{-1}$ and $40.00 \mathrm{mg} \mathrm{L}^{-1}$ of the active ingredient). The $0.00 \mathrm{mg} \mathrm{L}^{-1}$ concentration represented the control, without fungicide addition. The mycelial growth evaluation was performed with the aid of a digital pachymeter, by measuring the colonies diameter, when the fungus growth in the control treatment reached the Petri dish edge. The experimental design was completely randomized, with four replications. Concerning the fungitoxicity of active ingredients, a variation from non-toxic to highly fungitoxic was observed to the M. phaseolina isolate, with $\mathrm{IC}_{50}$ values ranging from $0.23 \mathrm{mg} \mathrm{L}^{-1}$ to $>40.00 \mathrm{mg} \mathrm{L}^{-1}$, being carbendazim the most efficient one $\left(\mathrm{IC}_{50}=0.23 \mathrm{mg} \mathrm{L}^{-1}\right)$. The fungus showed insensitivity to the active ingredients of fluquinconazole, metalaxyl, thiram and tolyfluanid.

KEY-WORDS: Glycine $\max \mathrm{L}$.; root rot; fungitoxicity; $\mathrm{IC}_{50}$.

1989), which is also known as M. cajan, M. sesame, Rhizoctonia bataticola or Sclerotium bataticola (Sartorato \& Rava 1994). In Brazil, the pathogen occurrence was first reported in Campinas, São Paulo State, in 1935, infecting bean roots (Coelho Neto 1994).

It is a polyphagous and cosmopolitan fungus that attacks many species of cultivated plants, including soybean, sorghum, peanut, cowpea,

1. Article received in Jan./2013 and accepted for publication in Dec./2013 (Registration number: PAT 22202).

2. Universidade de Passo Fundo (UPF), Faculdade de Agronomia e Medicina Veterinária, Laboratório de Fitopatologia e

Micologia, Passo Fundo, RS, Brasil.E-mails: rosanebaldiga@yahoo.com.br, avelinebio3@yahoo.com.br, andersondanelli@hotmail.com, erleireis@upf.br, sandramzoldan@ibest.com.br.

3. Universidade Técnica Estatal de Quevedo (UTEQ), Unidade de Pesquisa Científica e Tecnológica, Faculdade de Ciências Agrárias, Quevedo, Los Ríos, Equador.E-mail: felipegarces23@yahoo.com. 
sesame, sunflower, bean, cotton, black lentil, chili pepper, maize, tall grass prairie, tomato and watermelon, among others, affecting more than 500 plant species (Machado 1980, Singh et al. 1990, Wyllie 1993, Smith \& Carvil 1997, Su et al. 2001, Saleh et al. 2010, Mahdizadeh et al. 2011).

This pathogen was detected in the root epidermal tissues, at the maturity stage, in dry weather conditions (Almeida et al. 2003). The ideal temperature for the fungus is $28-32^{\circ} \mathrm{C}$, with temperature, moisture content and number of sclerotia $\mathrm{g}^{-1}$ of soil being important factors for its survival (Cardona 2006). According to Singh \& Singh (1982) and Santos et al. (1984), for almost all its hosts, the fungus is efficiently transmitted by seeds.

The charcoal rot is a disease whose importance has increased in recent seasons, being favored by high temperatures and water stress. Its control includes the use of clean seeds, as well as their treatment with fungicides. Crop rotation is not considered efficient, since the fungus has competitive saprophytic ability (Almeida et al. 2001, Pearson et al.1984).

Theoretically, the most practical and economical way of controlling the charcoal rot is using resistant cultivars, however, no genotype resistant to this disease has been identified so far (Almeida et al. 2001). In relation to its chemical control, in Brazil, there are no fungicides registered for this pathogen in soybean (Agrofit 2012). Thus, it is necessary to evaluate fungicides and their efficiency for controlling it.

Seed treatment with fungicides is a practice that has been used by an increasing number of farmers who grow soybean. The amount of seeds treated with fungicides, in the 1991/1992 crop season, did not reach $5 \%$ of the sown area, and it is currently around 90-95\%, in Brazil (Henning et al. 2010). Thus, it is necessary to evaluate the fungicides effectiveness to improve this pathogen control in soybean seeds.

This study aimed at determining the in vitro mycelial sensitivity and the $\mathrm{IC}_{50}$ values of a soybean M. phaseolina isolate to various fungicides, in order to verify the fungicides effectiveness in soybean seed treatments recommended by researchers.

\section{MATERIAL AND METHODS}

The experiment was conducted at the Universidade de Passo Fundo (UPF), Rio Grande do Sul State, Brazil, in 2011. The M. phaseolina mycelial sensitivity to fungicides was determined in a bioassay with the fungicides incorporation in solidifying potato dextrose agar (Fernandez 1993), similarly to the method described by Avozani (2011). The M. phaseolina mycelium growth sensitivity evaluation was performed in vitro to eight fungicides (Table 1) tested for a fungal strain isolated from soybean plant roots collected in a farm, in Passo Fundo.

The concentrations of $0.01 \mathrm{mg} \mathrm{L}^{-1}, 0.10 \mathrm{mg} \mathrm{L}^{-1}$, $1.00 \mathrm{mg} \mathrm{L}^{-1}, 10.00 \mathrm{mg} \mathrm{L}^{-1}, 20.00 \mathrm{mg} \mathrm{L}^{-1}$ and $40.00 \mathrm{mg} \mathrm{L}^{-1}$ of each fungicide active ingredient were used in the bioassay, being the $0.00 \mathrm{mg} \mathrm{L}^{-1}$ concentration considered the control, without fungicide addition.

For dilution, aliquots of each fungicide were transferred, with the aid of a micropipette, to a flask containing distilled sterile water (DSW), resulting in a $100 \mathrm{~mL}$ final volume (stock suspension 1). From the first fungicide suspension, $1.0 \mathrm{~mL}$ was transferred to a $99.0 \mathrm{~mL}$ flask containing DSW, considered the second dilution (stock suspension 2). Then, they were added to a dehydrated PDA (potato dextrose agarmerk) culture medium $\left(39 \mathrm{~g} \mathrm{~L}^{-1}\right)$, after autoclaving

Table 1. Fungicides used to determine the in vitro sensitivity of Macrophomina phaseolina to a soybean isolate (Passo Fundo, RS, 2011).

\begin{tabular}{llll}
\hline \multicolumn{1}{c}{ Trademark } & Active ingredient (a.i.) & a.i. concentration $\left(\mathrm{g} \mathrm{L}^{-1}\right)$ & \multicolumn{1}{c}{ Chemical group } \\
\hline Mayran & Thiram & $700 \mathrm{~g} \mathrm{~kg}^{-1}$ & Dimethyldithiocarbamate \\
Rovral & Iprodione & $500 \mathrm{~g} \mathrm{~kg}^{-1}$ & Dicarboximide \\
Derosal & Carbendazim & $500 \mathrm{~g} \mathrm{~L}^{-1}$ & Benzimidazol \\
Comet & Pyraclostrobin & $250 \mathrm{~g} \mathrm{~L}^{-1}$ & Estrobilurin \\
Atento & Fluquinconazole & $167 \mathrm{~g} \mathrm{~L}^{-1}$ & Triazol \\
Euparen & Tolyfluanid & $500 \mathrm{~g} \mathrm{~kg}^{-1}$ & Fenilsulfamide \\
Ridomil* & Metalaxyl & $40 \mathrm{~g} \mathrm{~L}^{-1}$ & Acilalaninate \\
BYF + TFS** & Penflufen + trifloxystrobin & $154+154 \mathrm{~g} \mathrm{~L}^{-1}$ & \\
\hline Source: Agrofit. * Ridomil Gold Bravo; ** Test product. & &
\end{tabular}


and cooling to obtain the desired concentrations, resulting in a $500 \mathrm{~mL}$ final volume.

The stock suspension 1 was used to get the $10.00 \mathrm{mg} \mathrm{L}^{-1}, 20.00 \mathrm{mg} \mathrm{L}^{-1}$ and $40.00 \mathrm{mg} \mathrm{L}^{-1}$ concentrations, and the stock suspension 2 to obtain the $0.01 \mathrm{mg} \mathrm{L}^{-1}, 0.10 \mathrm{mg} \mathrm{L}^{-1}$ and $1.00 \mathrm{mg} \mathrm{L}^{-1}$ concentrations. The vials were gently shaken and the medium poured into plastic Petri dishes $(90 \mathrm{~mm} \mathrm{x}$ $15 \mathrm{~mm}$ ) sterilized with formaldehyde vapor in a laminar flow. In order to obtain the stock suspension sand, the other concentrations of each active ingredient were based on the formula $\mathrm{C} 1 \times \mathrm{V} 1=\mathrm{C} 2 \times \mathrm{V} 2$, where $\mathrm{C} 1=$ more concentrated solution; $\mathrm{V} 1=$ volume needed for a more concentrated solution; $\mathrm{C} 2=$ final concentrated solution; and V2 = desired volume for the final solution.

The day after the culture media had been prepared, $6.0 \mathrm{~mm}$ diameter mycelia disks of M. phaseolina, taken from colonies after seven days of growth, were placed in the center of each Petri dish containing substrate amended with the fungicide concentrations. The dishes were sealed with plastic wrap and incubated in a growth chamber at $25 \pm 2^{\circ} \mathrm{C}$, for a 12-hour photoperiod, provided by three fluorescent lamps (Osram daylight $40 \mathrm{~W}$ ), positioned at $50 \mathrm{~cm}$ above the dishes.

The mycelial growth measurement was performed with a pachymeter, by measuring the colonies diameter in two perpendicular directions, when the fungal growth in the control treatment reached the dish edge.

A complete randomized experimental design was used, consisting of seven treatments and four replications, with each Petri dish being considered an experimental unit. The experiment was performed twice and the average of two tests was used in the statistical analysis.

The colony diameter measures $(\mathrm{mm})$ were transformed to control (inhibition) percentage and subjected to statistical analysis (fungicide $\mathrm{x}$ isolate). The Costat statistical program was used for the logarithmic regression analysis. The concentration to inhibit $50 \%$ of the fungus mycelial growth $\left(\mathrm{IC}_{50}\right)$ in the fungicides tested was calculated from the generated equations.

\section{RESULTS AND DISCUSSION}

The monitoring of fungus sensitivity to fungicides is important for maximizing its control efficiency. The $\mathrm{IC}_{50}$ is specific and constant for a particular chemical agent and to a particular pathogen. The substance is fungicidal in a low concentration, and a low $\mathrm{IC}_{50}$ value represents a high fungicidal action or fungicidal power (Reis et al. 2007).

The fungus sensitivity to a fungicide, or a chemical fungitoxicity, is measured by parameters such as the $\mathrm{IC}_{50}$ (concentration that inhibits 50\% of the mycelium growth and spore germination) (Sharvelle 1961, Torgeson 1967, Edgington et al. 1971, Reis et al. 2010).

By measuring the $M$. phaseolina colony diameter in each treatment, the $\mathrm{IC}_{50}$ values (Table 2) were calculated. The coefficients of determination ranged $0.87-0.98$. The sensitivity of a fungus to a toxic substance (fungicide), or the measurement of the chemical toxicity to a fungus, is expressed by $\mathrm{ED}_{50}$ (effective dose), $\mathrm{EC}_{50}$ (effective concentration) or $\mathrm{IC}_{50}$ (inhibitory concentration). The fungicides that showed the highest inhibition level $\left(\mathrm{IC}_{50}\right.$ below

Table 2. Fungicide, regression equation, coefficient of determination $\left(\mathrm{R}^{2}\right)$, sensitivity and $50 \%$ inhibitory concentration of mycelium growth $\left(\mathrm{IC}_{50}\right.$ ) of Macrophomina phaseolina (Passo Fundo, RS, 2011).

\begin{tabular}{|c|c|c|c|c|}
\hline \multirow{2}{*}{ Fungicide } & \multirow{2}{*}{ Regression equation* } & $\mathrm{R}^{2}$ & $\mathrm{IC}_{50} * *$ & \multirow{2}{*}{$\mathrm{S}^{(1)}$} \\
\hline & & $\%$ & $\mathrm{mg} \mathrm{L}^{-1}$ & \\
\hline Carbendazim & $y=-10.9 \operatorname{Ln}(x)+34.18$ & 0.87 & 0.23 & HS \\
\hline Metalaxyl & $y=-0.15 \operatorname{Ln}(x)+99.52$ & 0.83 & $>40$ & I \\
\hline Fluquinconazol & $y=-1.73 \operatorname{Ln}(x)+94.90$ & 0.80 & $>40$ & I \\
\hline Iprodione & $y=-13.1 \operatorname{Ln}(x)+51.60$ & 0.94 & 1.13 & MS \\
\hline Penflufen + trifloxystrobin & $y=-10.8 \operatorname{Ln}(x)+47.66$ & 0.98 & 0.81 & HS \\
\hline Pyraclostrobin & $y=-9.82 \operatorname{Ln}(x)+66.87$ & 0.91 & 5.57 & MS \\
\hline Thiram & $y=-2.18 \operatorname{Ln}(x)+93.86$ & 0.60 & $>40$ & I \\
\hline Tolyfluanid & $y=-6.60 \operatorname{Ln}(x)+80.50$ & 0.80 & $>40$ & I \\
\hline
\end{tabular}

$* \mathrm{y}=$ percentage of mycelial growth inhibition; $\mathrm{x}=$ fungicide concentration. ${ }^{*}$ Calculated by the concentration equation $\left(\mathrm{mg} \mathrm{L}^{-1}\right) .{ }^{(1)}$ Sensitivity of Macrophomina phaseolina to fungicide: high sensitivity (HS), moderate sensitivity (MS), low sensitivity (LS), insensitive (I). Average of two experiments. 
$\left.1.00 \mathrm{mg} \mathrm{L}^{-1}\right)$ were carbendazim and penflufen + trifloxystrobin (testing fungicide) (Figure 1).

In the two experiments, an average concentration of $0.23 \mathrm{mg} \mathrm{L}^{-1}$ for the active ingredient of the carbendazim $\mathrm{IC}_{50}$ value was observed. This fungicide proved to be the most fungitoxic to the M. phaseolina isolate (Table 2 and Figure 3). The penflufen + trifloxystrobin mixture was also efficient, showing a $\mathrm{CI}_{50}$ of $0.81 \mathrm{mg} \mathrm{L}^{-1}$. For both fungicides, this isolate was considered highly sensitive.

Edgington et al. (1971) proposed the following criteria to frame a fungicidal substance, concerning fungitoxicity: $\mathrm{ED}_{50}<1 \mathrm{mg} \mathrm{L}^{-1}=$ highly fungitoxic, $\mathrm{ED}_{50}$ of $1-50 \mathrm{mg} \mathrm{L}^{-1}=$ moderately fungitoxic and $\mathrm{ED}_{50}>50 \mathrm{mg} \mathrm{L}^{-1}=$ non-toxic. The same authors reported an $\mathrm{IC}_{50}$ of $1.13 \mathrm{mg} \mathrm{L}^{-1}$ for the iprodione fungicide, which is considered a moderately fungitoxic chemical.

The $\mathrm{IC}_{50}$ represents the chemical concentration to inhibit (or control) $50 \%$ of the mycelial growth $(\mathrm{mm}$ ) or potentially viable spores germination (\%), lesions (leaf spots) number $\mathrm{cm}^{-2}$ and uredia density $\mathrm{cm}^{-2}$.
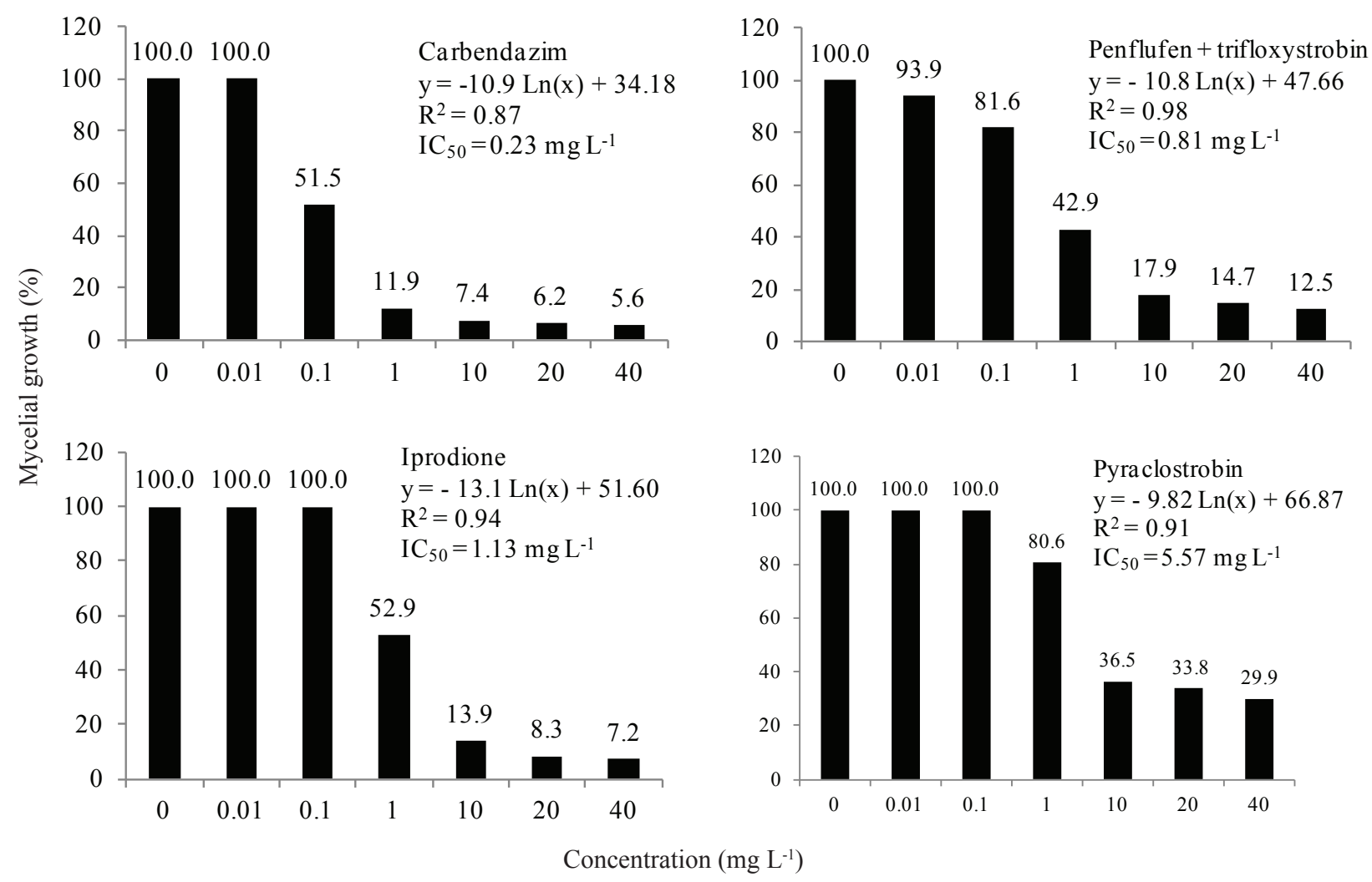

Figure 1. In vitro mycelial growth of Macrophomina phaseolina isolates, in seven concentrations ( $\mathrm{mg} \mathrm{L}^{-1}$ a.i.) of carbendazim, penflufen + trifloxystrobin, iprodione and pyraclostrobin (Passo Fundo, RS, 2011). y = mycelial growth; $x=$ fungicide concentration; $\mathrm{IC}_{50}=50 \%$ inhibitory concentration for mycelial growth. or not to a given molecule. If a fungus is sensitive to a fungicide, it displays fungitoxicity, otherwise, it is non-toxic. If the fungicide shows no fungitoxicity, the fungus is then considered insensitive (Reis et al. 2007). Not all chemicals are toxic to fungi and a fungicide does not control all fungi (Sharvelle 1961, Torgeson 1967, Edgington et al. 1971, Reis et al. 2010).

The active ingredients fluquinconazole, metalaxyl, thiram and tolyfluanid (Table 2) showed $\mathrm{IC}_{50}$ values higher than $40.00 \mathrm{mg} \mathrm{L}^{-1}$, indicating the isolate insensitivity. For the active ingredient pyraclostrobin, the pathogen was considered moderately sensitive, with $\mathrm{IC}_{50}$ value of $5.57 \mathrm{mg} \mathrm{L}^{-1}$ and coefficient of determination of 0.91 .

According to Edginton et al. (1971), fluquinconazole, metalaxyl, tolyfluanid and thiram can be classified as non-toxic active ingredients to the M. phaseolina isolate. None of the fungicide treatments inhibited $100 \%$ of the fungal mycelium growth (Figures 1 and 2). 


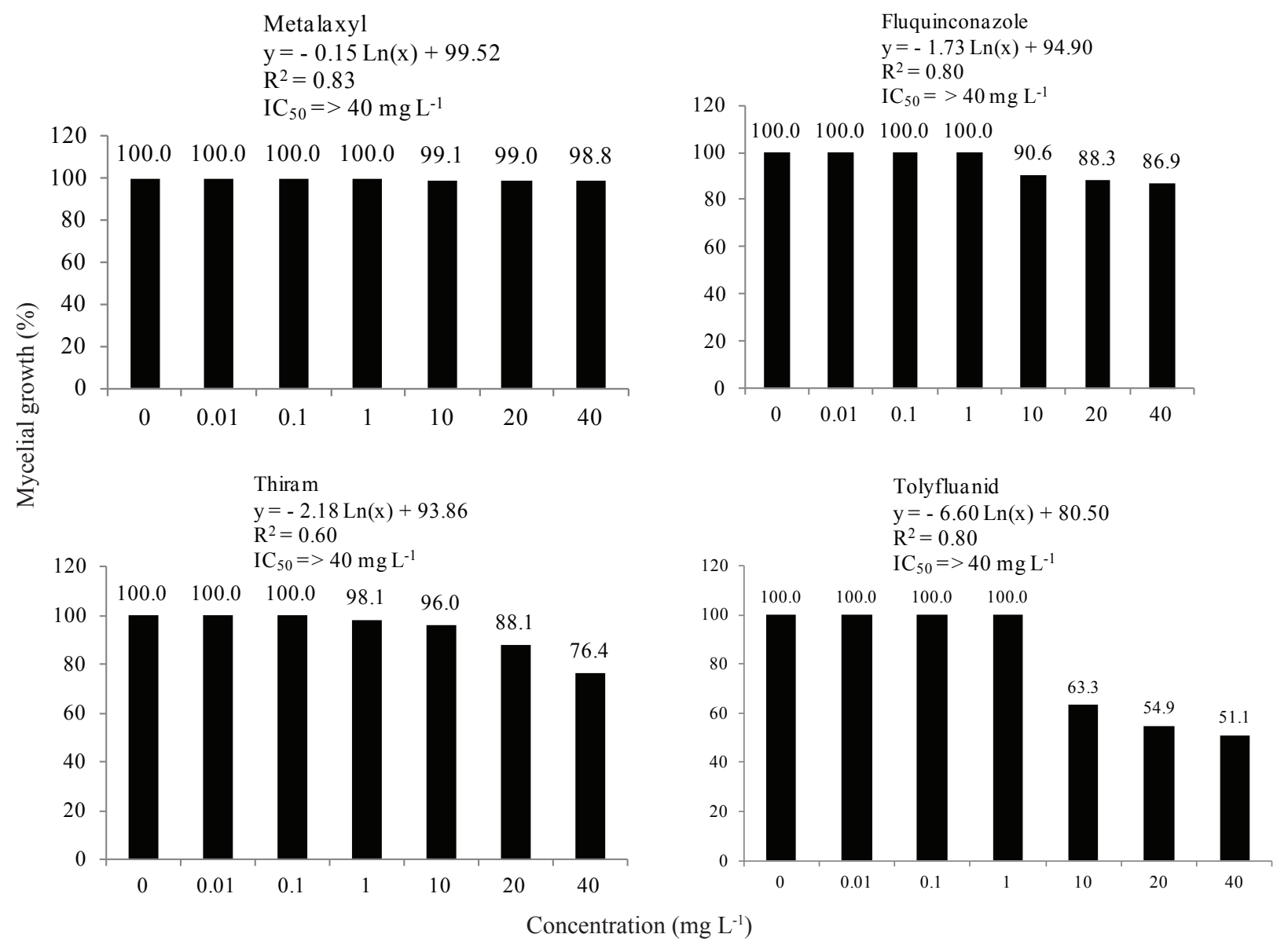

Figure 2. In vitro mycelial growth of Macrophomina phaseolina isolates, in seven concentrations (mg L $\mathrm{L}^{-1}$ a.i.) of metalaxyl, fluquinconazole, thiram and tolyfluanid (Passo Fundo, RS, 2011). $\mathrm{y}=$ mycelial growth; $\mathrm{x}=$ fungicide concentration; $\mathrm{IC}_{50}=$ $50 \%$ inhibitory concentration for mycelial growth.

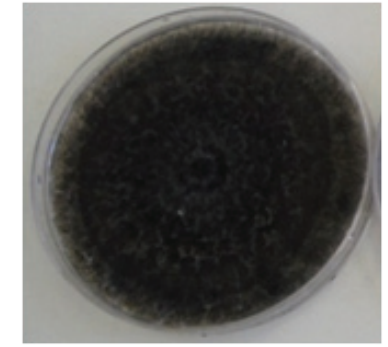

$0.00 \mathrm{mg} \mathrm{L}^{-1}$

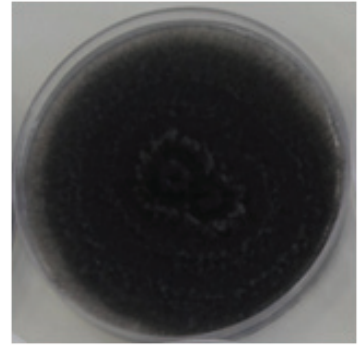

$0.01 \mathrm{mg} \mathrm{L}^{-1}$

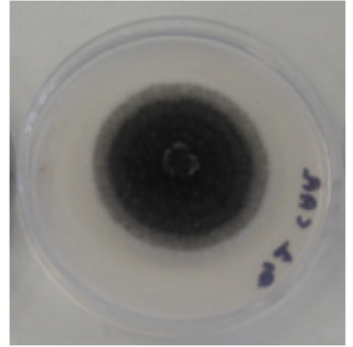

$0.10 \mathrm{mg} \mathrm{L}^{-1}$

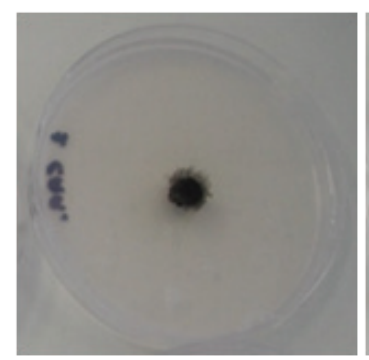

$1.00 \mathrm{mg} \mathrm{L}^{-1}$

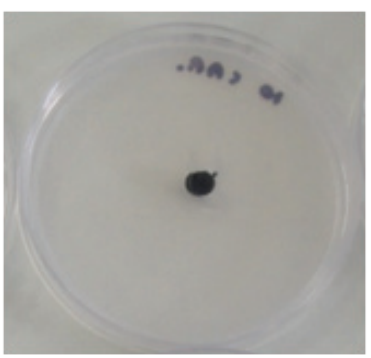

$10.00 \mathrm{mg} \mathrm{L}^{-1}$

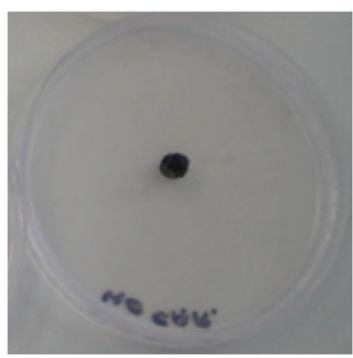

$20.00 \mathrm{mg} \mathrm{L}^{-1}$

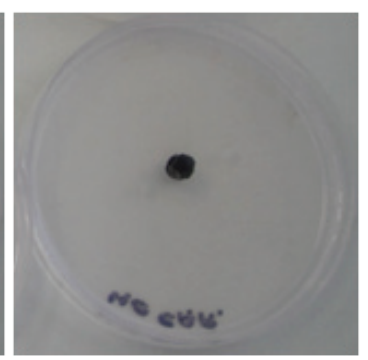

$40.00 \mathrm{mg} \mathrm{L}^{-1}$

Figure 3. Mycelial growth of Macrophomina phaseolina soybean isolate, in a culture medium supplemented with different concentrations of carbendazim (Passo Fundo, RS, 2011). 
Only a few studies have reported the sensitivity of this fungus to fungicides. Menten et al. (1976), studying the effect of three fungicides on the mycelium growth of $M$. phaseolina, concluded that benomyl promoted a greater mycelial growth inhibition than pentachloronitrobenzene (PCNB) and carboxin. Benomyl, a benzimidazol compound, belongs to the same chemical group of carbendazim.

In a study conducted by Braga et al. (2003), using benomyl and thiophanate methyl, in a Vigna unguiculata (L.) Walp. seed treatment, the M. phaseolina transmission did not differ between the two fungicides. In the present study, the $\mathrm{IC}_{50}$ of the active ingredient carbendazimcan showed to be a viable alternative for controlling the fungus in soybean seeds. However, the effective control of M. phaseolina by seed treatment with fungicides has not been considered.

Just a few scientific studies have reported the fungicides performance for controlling this fungus. The first step in the search for promising products which chemically control this pathogen is to identify the fungus isolates sensitivity to fungicides available in the market. The $\mathrm{IC}_{50}$ values for the fungicides were different in magnitude, showing chemical toxicity to non-toxicity to the isolate.

\section{CONCLUSIONS}

1. The active ingredients carbendazim and penflufen + trifloxystrobin were the most powerful ones to control M. phaseolina, or the most efficient in soybean seed treatments.

2. The M. phaseolina isolate showed insensitivity to the active ingredients fluquinconazole, metalaxyl, thiram and tolyfluanida.

\section{REFERENCES}

ALMEIDA, A. M. R. et al. Genotypic diversity among Brazilian isolates of Macrophomina phaseolina revealed by RAPD. Fitopatologia Brasileira, Brasília, DF, v. 28, n. 3, p. 279-285, 2003.

ALMEIDA, A. M. R. et al. Macrophomina phaseolina em soja: sistemas de semeadura, sobrevivência em restos de cultura e diversidade genética. Londrina: Embrapa Soja, 2001.

AVOZANI, A. Sensibilidade de Corynespora cassiicola, isolados da soja, a fungicidas in vitro. 2011. $121 \mathrm{f}$.
Dissertação (Mestrado em Agronomia) - Universidade de Passo Fundo, Passo Fundo, 2011.

BANCO DE INFORMAÇÕES SOBRE OS PRODUTOS AGROTÓXICOS (Agrofit). Base de dados de produtos agrotóxicos e fitossanitários. Brasília, DF: Ministério da Agricultura e do Abastecimento, 2012.

BRAGA, N. A.; GOMES PESSOA, M. N.; TEÓFILO, E. M. Tratamento químico e biológico de sementes de caupi, Vigna unguiculata (L.) Walp., visando o controle de Macrophomina phaseolina (Tass.) Goid. Revista Ciência Agronômica, Fortaleza, v. 34, n. 2, p. 193-199, 2003.

CARDONA, R. Distribución vertical de esclerocios de Macrophomin phaseolina en um suelo infestado naturalmente en el estado Portuguesa. Revista Facultad de Agronomía, Maracaibo, v. 23, n. 3, p. 284-291, 2006.

COELHO NETO, R. A. Metodologia e avaliação da resistência de feijoeiro à podridão cinzenta do caule, em laboratório e casa-de-vegetação. 1994. 54 f. Dissertação (Mestrado em Agronomia) - Universidade Federal de Viçosa, Viçosa, 1994.

EDGINGTON, L. V.; KHEW, K. L.; BARROW, G. L. Fungitoxic spectrum of benzimidazole compounds. Phytopathology, Saint Paul, v. 61, n. 1, p. 42-44, 1971.

FERNANDEZ, M. R. Manual para laboratório de fitopatologia. Passo Fundo: Embrapa-CNPT, 1993.

HENNING, A. A. et al. Importância do tratamento de sementes de soja com fungicidas na safra 2010/2011, ano de "La Niña". Londrina: Embrapa Soja, 2010.

MACHADO, C. C. Esporulação de Macrophomina phaseolina (Tassi) Goid. e viabilidade do método de inoculação de esporos em estudos de seleção de germoplasma resistente. 1980.75 f. Dissertação (Mestrado em Agronomia) - Escola Superior de Agricultura "Luiz de Queiroz”, Piracicaba, 1980.

MAHDIZADEH, V.; SAFAIE, N.; AGHAJANI, M. A. New hosts of Macrophomina phaseolina in Iran. Journal of Plant Pathology, Bari,v. 93, n. 4 (supplement), p. S4.63-S4.89, 2011.

MENTEN, J. O. M. et al. Efeito de alguns fungicidas no crescimento micelial de Macrophomina phaseolina (Tass.) Goid. in vitro. Fitopatologia Brasileira, Brasília, DF, v. 1, n. 2, p. 57-66, 1976.

PEARSON, C. A. S. et al. Colonization of soybean roots by Macrophomina phaseolina. Plant Disease, Saint Paul, v. 68, n. 12, p. 1086-1088, 1984.

REIS, E. M.; FORCELINI, C. A.; REIS, A. C. Manual de fungicidas: guia para o controle de doenças de plantas. Passo Fundo: UPF, 2007. 
REIS, E. M.; REIS, A. C.; CARMONA, M. A. Manual de fungicidas: guia para o controle químico de doenças de plantas. Passo Fundo: UPF, 2010.

SALEH, A. A. et al. Related nest of Macrophomina phaseolina isolates from tall grass prairie, maize, soybean and sorghum. Molecular Ecology, Malden, v. 19, n. 1, p. 79-91, 2010.

SANTOS, A. F.; ATHAYDE, J. T.; DAN, E. L. Microflora associada às sementes de feijão (Phaseolus vulgaris) no Estado do Espírito Santo. Fitopatologia Brasileira, Brasília, DF, v. 9, n. 3, p. 379, 1984.

SARTORATO, A.; RAVA, C. A. Principais doenças do feijoeiro comum e seu controle. Brasília, DF: EmbrapaSPI, 1994.

SHARVELLE, E. G. The nature and uses of modern fungicides. Minneapolis: Burgess Publishing Company, 1961.

SINCLAIR, J.; BACKMAN, P. A. Compendium of soybean diseases. Saint Paul: American Phytopathological Society, 1989.
SINGH, S. K.; NENE, Y. L.; REDDY, M. V. Additions to the host range of Macrophomina phaseolina. Plant Disease, Saint Paul, v. 74, n. 10, p. 828, 1990.

SINGH, T.; SINGH, D. Transmission of seed-borne inoculum of Macrophomina phaseolina from seed to plant. Proceedings: Plant Sciences, Bangalore, v. 91, n. 4, p. 357-370, 1982.

SMITH, G. S.; CARVIL, O. N. Field screening of commercial and experimental soybean cultivars for their reaction to Macrophomina phaseolina. Plant Disease, Saint Paul, v. 81, n. 4, p. 363-368, 1997.

SU, G. et al. Host specialization in the charcoal rot fungus, Macrophomina phaseolina. Phytopathology, Saint Paul, v. 91, n. 2, p. 120-126, 2001.

TORGESON, D. C. Determination and measurement of fungitoxicity. In: TORGESON, D. C. Fungicides: an advanced treatise. New York: Academic Press, 1967. p. $162-167$.

WYLLIE, T. D. Compendium of soybean diseases. 3rd ed. Saint Paul: American Phytopathological Society, 1993. 